\title{
The Effect of Website Quality and Brand Image on Consumer Purchase Decisions with Trust as an Intervening Variable (Case Study at Bukalapak.com)
}

\author{
Fitrah All Burman \\ Magister Management Student, Mercubuana University, Jakarta, Indonesia \\ M. Ali Iqbal \\ Senior Lecturer in Magister Management Program, Mercubuana University, Jakarta, Indonesia
}

\begin{abstract}
This study aims to analyze the effect of Website Quality and Brand Image on Consumer Purchase Decision with Trust as Intervening Variable (Case Study on Bukalapak.com). The object of research used is Bukalapak.Com customer as many as 100 respondents. While the determination of the sample using purposive random sampling technique. The analytical technique used is Structural Equation Modeling (SEM). The result of analysis in this research shows that (1) website quality has positif and significant effect on purchasing decision, (2) Brand Image has positif and significant effect on purchase decision, (3) Trust has a positif and significant effect on purchase decision, (4) website quality has positif and significant effect on trust, and (5) Brand image has positif and significant effect on trust.
\end{abstract}

Keywords: E-Commerce, website quality, brand image, trust, purchase decision.

DOI: $10.7176 / \mathrm{EJBM} / 11-28-09$

Publication date:October $31^{\text {st }} 2019$

\section{INTRODUCTION}

\subsection{Research Background}

The communication, media and informatics technology that is growing rapidly nowadays coupled with the expanding development of global information infrastructure, brings influence, ways and patterns of business activities in the trade industry, social and political governance (Ardyanto, et. al, 2015). This is possible because the presence of the internet makes people able to connect without any space and time limits.

One sector that has been directly affected by the development of the internet is business activity (online business). Online business is an electronic commerce (e-commerce) activity where activities sell and buy products or services through the internet. (Hausman and Siekpe, 2009). Jusoh and Ling (2012) define online shopping as a process where a customer makes payments through the internet for goods and services that he buys. The internet has changed the flow of trade in the world of conventional business to become all digital. Today's business mechanism is built into a networked community. Slowly but surely, internet penetration has changed consumer purchasing behavior in meeting their needs (Pratiwi, 2012).

One of the e-commerce that we know today in Indonesia is Bukalapak.com which was officially established on January 10, 2011. The company was created with the aim of empowering Indonesian small and medium enterprises by providing a forum for SMEs to sell their products. Bukalapak.com provides a means of selling from consumers to consumers (C2C) anywhere. Anyone who can open an online store then prepares prospective buyers from all over Indonesia, both units and in large quantities. Individual users or companies can buy and sell products, both new and used, such as bicycles, cellphones, baby equipment, gadgets, accessories, computers, household appliances, clothing, electronics, and others. 


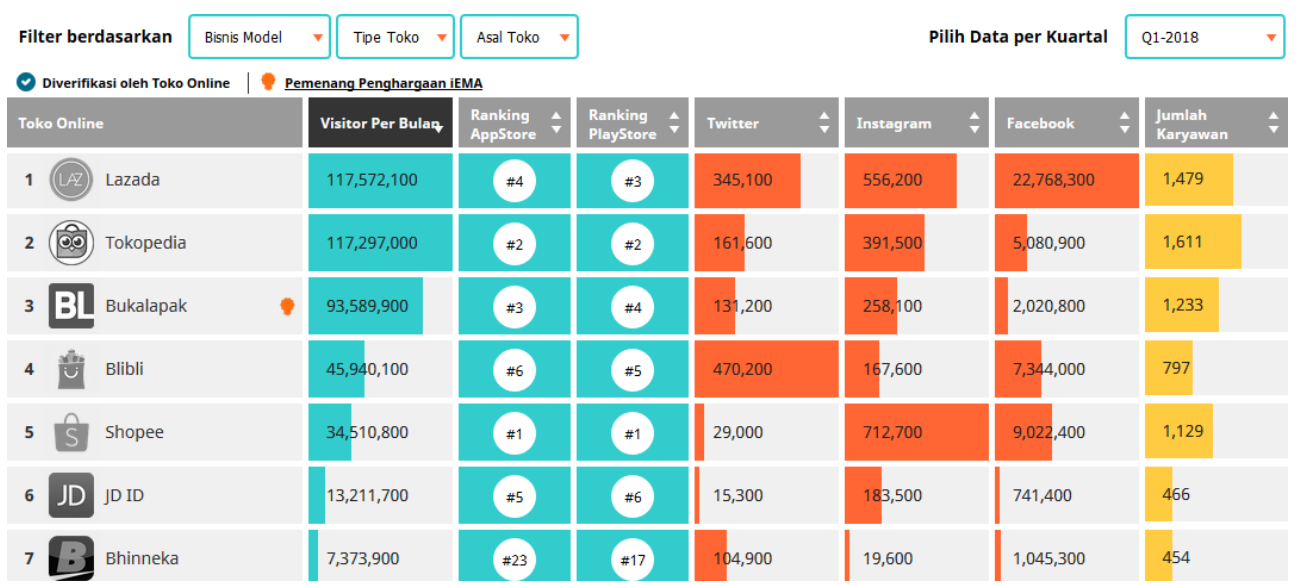

Source: ipriceinsights

Figure 1.1 Indonesian e-commerce data for 2018

Based on Figure 1.1 above, it is known that Bukalapak.com has an average number of visitors per month that is still lower than that of Tokopedia and Lazada. The low number of visitors shows that Bukalapak.com is not the first choice for consumers to shop online. In addition, it is known that applications owned by Bukalapak.com have ordinary ratings when compared to applications owned by other e-commerce companies. This shows that the quality of the Bukalapak.com website needs to be further evaluated

Trust has an important role. If observed, the complexity of trust in the online world is classified as higher, because let alone on online transactions, only face-to-face transactions still hear many cases of fraud. This is also one of the factors that causes the opportunity to be able to create trust in the online shopping system to be less than selling conventional ways (Ananda, 2017).

According to Sarwono and Prihartono (2012), a company website must present about the company in a virtual company so that customers trust and conduct online transactions through the company's website. The quality of a good website will make internet service users more interested in searching for information and websites more often (Sujana and Ni Wayan, 2016).

Mustikarillah (2011), the better the brand image of the product being sold then it will increase on consumer purchasing decisions. Brand image can be used as a guideline for consumers to be bought online at an e-commerce company (Herwin and Dion, 2016). This is because consumers cannot use the product physically. Brand image that has an impact on trust. This explains that brand image perceived by consumers influences the emergence of consumer trust. Brand images that are perceived by consumers such as views about quality, service, companies that can make consumers believe. (Cindy, 2014).

\subsection{Research Objective and Questions}

The objective of this research is to develop a model to measure the purchase decision in Indonesian e-commerce related to website quality, brand image, and trust. This study includes the following theoretical objectives:

1. To introduce a model to the purchase decision in Indonesian e-commerce

2. To find the relationships between website quality, brand image, and trust related to the purchase decision in Indonesian ecommerce.

Based on explaination set fifth above, the research questions can be defined and formulated as follows:

1. How is the relationship between website quality and purchase decision in Indonesian e-commerce?

2. How is the relationship between brand image and purchase decision in Indonesian e-commerce?

3. How is the relationship between website quality and trust?

4. How is the relationship between brand image and trust?

5. How is the relationship between trust and purchase decision?

\section{THEORETICAL FRAMEWORK AND HYPOTHESES}

\subsection{Website Quality}

According to Laudon and Laudon (2012) a website is a system with universally accepted standards for storing, retrieving, and displaying information in a network environment. He said that two kinds of functions were given by a website: First, information sources that can provide various kinds of information needed by users. This information can be catalogs, databases, archives, bulletins and so on and second, interactive service that can serve activities between users and servers. Suryani (2013) stated that a quality website is one that in its design facilitates interaction with consumers. According to Chaffey and Smith (2013), the dimensions of website quality are arranged based on 3 (three) areas, namely usability, information quality and service interaction quality. Shalini and Hemamalini (2015) in their research state that website quality has a significant effect on purchasing decisions. 
Brata, Shilvana and Hapzi (2017) also stated that product quality, price, promotion and location simultaneously have a positive and significant effect on purchasing decision variable meanwhile Hasanov and Haliyana (2015) and Piarna R (2011) in the study showed that the quality of the website had no significant effect on purchasing decisions. Website quality also has relationship to trust. Chang et al. (2014), Ganguly and Satya (2010) also show the same thing in their research, namely the quality of the website influences trust.

\subsection{Brand image}

Kotler and Keller (2012) define brand image as a name, term, sign, symbol, design, or a combination of all that is intended to identify an item or service from a seller or group of sellers and to distinguish it from other competitors. Zulastari and Aditya (2016) in the results of his research show that brand image has a significant effect on consumer purchasing decisions. The same results are also shown in Shah et al. (2012) which shown that brand image has a significant effect on consumer purchasing decisions. Brand image also has relationship to trust. Fianto et al. (2014) stated in his research showed that brand Image has a significant effect on trust. Sitorus and Roni 2015 state the same thing, namely that brand image has a significant effect on customer trust.

\subsection{Trust}

Trust is the belief that one will find what is desired on the exchange partner. Trusts involve a person of willingness to behave in a certain way because of the belief that his partner will give what he or she hopes for and has that the words of someone else's promise or assertion can be trusted by Barnes and Vidgen (2001). According to Elrado, (2014: 48) trust is the willingness of individuals to depend on others involved in exchange because the individual has confidence to the other party. According to Mowen and Minor (2012) consumer trust is all knowledge held by consumers and all conclusions made by consumers about objects, attributes and benefits. Consumer trust or consumer knowledge concerns the belief that a product has various attributes, and benefits from various attributes (Sumarwan, 2011). Al-Ekam et.al 2012 states that the results of the study showed that Trust has a significant effect on consumer purchasing decisions. Ardyanto et al. (2015) and Mahkota et al. (2014) showed the same results of research, namely that trust has a significant effect on consumer purchasing decisions.

\subsection{Purchase Decision}

According to Peter and Olson (2006), the purchase decision is an integration process that combines knowledge to evaluate two or more alternative behaviours and choose one of them. According to Tjiptono (2015), the purchasing decision process can be broadly categorized into three main stages: pre-purchase, consumption and post-purchase evaluation. According to Schiffman and Kanuk (2008) the purchasing decision is a selection of two or more alternative choices. In other words, alternative choices must be available to someone when making a decision. The purchase decision making process requires searching or receiving different information. According to Kotler and Armstrong (2012), the purchase decision process for new products has only 5 stages, namely awareness, interest, evaluation, trying and adoption. Lovelock and Wirtz (2011) states that the decision making process is awareness of needs, information seeking, evaluating alternatives, and purchasing decision making. According to Kotler and Amrstrong (2008), that the purchase decision process consists of problem recognition, information search, alternative evaluation, purchasing decision and behavior after purchase

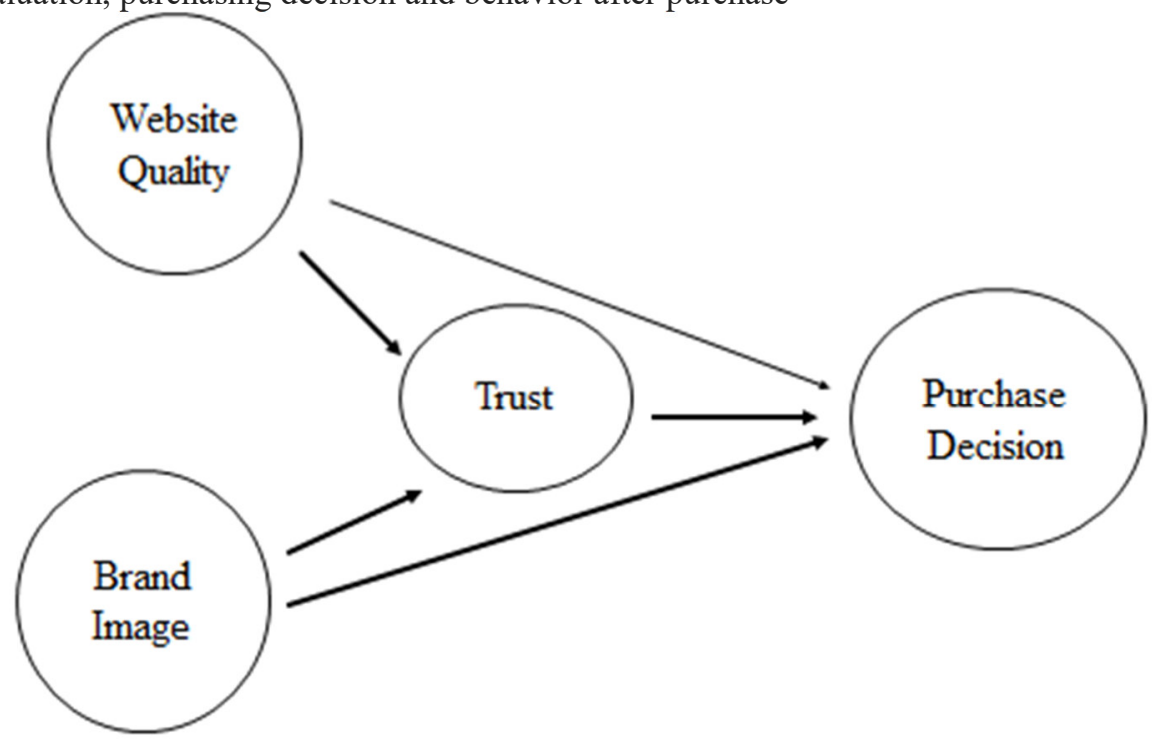

Figure 2.1. Research Model 


\section{RESEARCH METHODS}

The type of research used for this study is to use analytic descriptive research. This study uses 100 samples that represent the population at visitors to Bukalapak.com. Data obtained using quantitative data that are structured, using a Likert scale 1-5, from very agree to disagree. The data in this study were obtained through questionnaires, therefore the research instrument needs to be tested to find out the data quality test which includes reliability test and validity test where data collection is done using the Structural Equation Modeling (SEM) approach using SmartPLS software version 3.2.7. PLS is a structural equation model (SEM) based on variance or component.

\section{RESULTS AND DISCUSSIONS}

This research was conducted on 100 people from Bukalapak.com customers, but only 96 data can be processed, due to completeness of filling. The majority of respondents are female with the majority aged 21-30 years with the majority of spending every month 2-5 million rupiah.

The results of processing using the SmartPLS above initially did not meet convergence validity because there are still quite a number of indicators that have a value of loading factors below 0.50 so that it needs to be eliminated

Table 1. Outer Loading (Measurement Model)

\begin{tabular}{|c|c|c|c|}
\hline Website Quality & Before Eliminate & Eliminate 1 & After Eliminate \\
\hline WQ1 & .961 & .961 & .961 \\
\hline WQ2 & .963 & .963 & .963 \\
\hline WQ3 & .964 & .964 & .964 \\
\hline Brand Image & Before Eliminate & Eliminate 1 & After Eliminate \\
\hline BI1 & .981 & .981 & .981 \\
\hline BI2 & .984 & .984 & .984 \\
\hline BI3 & .979 & .979 & .979 \\
\hline Trust & Before Eliminate & Eliminate 1 & After Eliminate \\
\hline T1 & -.100 & -.100 & - \\
\hline T2 & .972 & .972 & .972 \\
\hline T3 & .966 & .966 & .966 \\
\hline T4 & .973 & .973 & .973 \\
\hline Purchase Decision & Before Eliminate & Eliminate 1 & After Eliminate \\
\hline PD2 & .715 & .715 & .715 \\
\hline PD3 & .093 & .093 & - \\
\hline PD4 & .958 & .958 & .958 \\
\hline PD5 & .953 & .953 & .953 \\
\hline
\end{tabular}

Source: Data Processing by PLS 2018

Table 2. Average Variance Extracted (AVE)

\begin{tabular}{|c|c|c|}
\hline Variable & AVE & Vilidity \\
\hline Website Quality (WQ) & .927 & Valid \\
\hline Brand Image (BI) & .963 & Valid \\
\hline Trust (T) & .942 & Valid \\
\hline Purchase Decision (PD) & .810 & Valid \\
\hline
\end{tabular}

Table 3. Composite Reliability

\begin{tabular}{|c|c|c|}
\hline Variable & Composite Reliability & Reliability \\
\hline Website Quality (WQ) & .974 & Reliable \\
\hline Brand Image (BI) & .987 & Reliable \\
\hline Trust (T) & .980 & Reliable \\
\hline Purchase Decision (PD) & .944 & Reliable \\
\hline
\end{tabular}


Table 4. Result for Inner Weight

\begin{tabular}{|c|c|c|c|c|}
\hline & Original Sample Estimate & $\begin{array}{c}\text { Mean of } \\
\text { Subsamples }\end{array}$ & $\begin{array}{c}\text { Standard } \\
\text { Deviation }\end{array}$ & T-Statistics \\
\hline $\mathrm{KW} \rightarrow \mathrm{KP}$ & .105 & .193 & .066 & 2.913 \\
\hline $\mathrm{BI} \rightarrow \mathrm{KP}$ & .685 & .769 & .079 & 9.717 \\
\hline $\mathrm{K} \rightarrow \mathrm{KP}$ & .216 & .210 & .092 & 2.242 \\
\hline $\mathrm{KW} \rightarrow \mathrm{K}$ & .391 & .391 & .091 & 4.276 \\
\hline $\mathrm{BI} \rightarrow \mathrm{K}$ & .375 & .376 & .072 & 5.180 \\
\hline
\end{tabular}

Source: Data Processing by PLS 2018

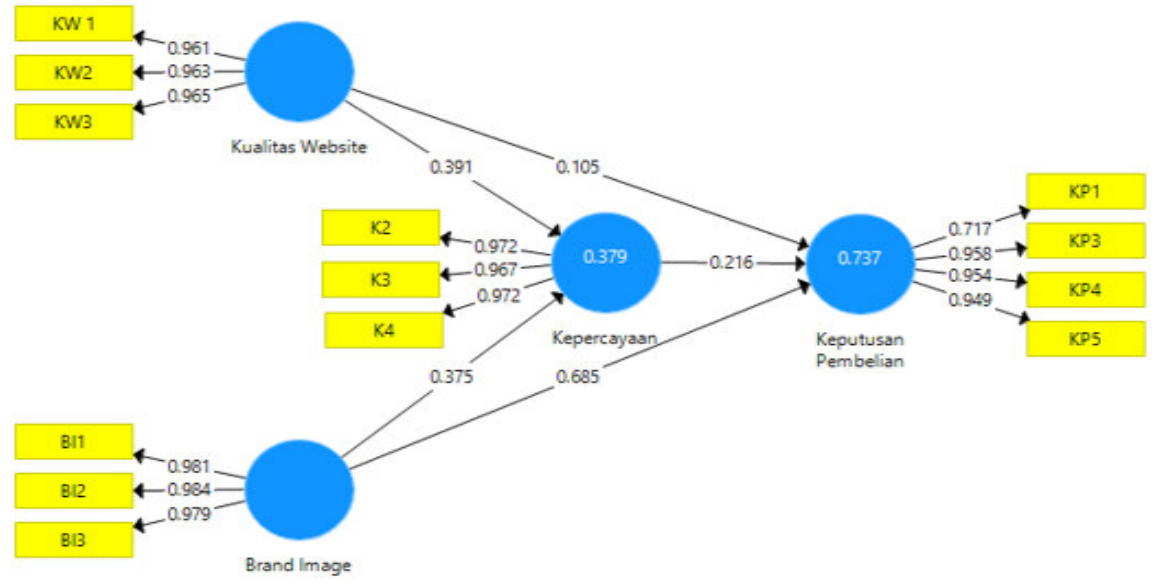

Figure.3.1. PLS Results

It was seen in Tabble 4 that the influence of website quality (KW) with positive purchasing decision (KP) was 0.105 and was significant at $2.913>1.96$. The effect of brand image $(\mathrm{BI})$ with positive purchasing decision $(\mathrm{KP})$ is 0.685 and is significant at $9.717>1.96$. The effect of trust $(\mathrm{K})$ with positive purchasing decision $(\mathrm{KP})$ is 0.216 and is significant at $2.224>1.96$. The effect of website quality $(\mathrm{KW})$ with positive trust $(\mathrm{K})$ is 0.391 and is significant at $4.276>1.96$. The influence of brand image $(\mathrm{BI})$ with positive trust $(\mathrm{K})$ is 0.375 and is significant at $5.180>1.96$.

\section{CONCLUSIONS AND RECOMMENDATIONS}

\subsection{Practical implications}

In improving the purchade decision, we recommend that the online company consider brand image, website quality, and trust because these three variables have a significant influence on purchasing decesion. Therefore, the online shop should analyse overtime the brand image, website quality and trust such that all that three variables can be adjusted.

\subsection{Theoretical contributions}

Brand image has a positive and significant influence on the purchasing decision. This finding supports the previous research by Zulastari and Aditya (2016) in the results of his research show that brand image has a significant effect on consumer purchasing decisions. The same results are also shown in Shah et al. (2012) which shown that brand image has a significant effect on consumer purchasing decisions. Website quality has a positive and significant effect on purchasing decisions. This research was supported by Shalini and Hemamalini (2015) in their research stated that website quality has a significant effect on purchasing decisions. Trust has a positive and significant effect on the purchase decision. This research was supported by Al-Ekam et.al 2012 stated that the results of the study showed that trust has a significant effect on consumer purchasing decisions. Ardyanto et al. (2015) and Mahkota et al. (2014) showed the same results of research, namely that trust has a significant effect on consumer purchasing decisions.

\subsection{Limitations of research}

This study did not explore other variables that also affect purchasing decision such as customer satisfaction, customer value and consumer commitment. This study was conducted at only one online shop and therefore cannot be generalised to online shop in different shop in Indonesia. The most important restriction of this research is the cross-sectional nature of the study. It is therefore recommended that causal interpretations of the results be undertaken with caution. As the measurement occurred at a single point in time, whether the conclusions still apply 
to the long-term cannot be determined. A longitudinal study may provide a decisive answer to the question of whether the conclusions of this research still apply in the long-term.

\subsection{Future research direction}

Additional research should expand the object of the research to more than one online shope such that the results can be generalised to all online shop in Indonesia. As previously noted, this study was conducted at a single point in time. Longitudinal research will have more moments of measurement over time.

\section{REFERENCES}

Al-Ekam, Jamal Mohammed Esmail., Nik Kamariah Nik Mat., Salniza Md. Salleh., Norashikin Binti Baharom., Tuan Rohasnida Binti Tuan Teh., Noor Aida Binti Noh., and Nor Ermawati Binti Hussain. (2012). "The Influence of Trust, Advertising, Family on Intention and Actual Purchase of Local Brand in Yemen". American Journal of Economics.

Ananda, Lingga D. (2017). "Dinamika Trust pada Pemasaran Online di Media Sosial”. Jurnal Komunikasi Indonesia. Vol. 5 No. 1.

Ardyanto, Denni., Heru Susilo dan Riyadi. (2015). "Pengaruh Kemudahan dan Kepercayaan menggunakan ECommerce terhadap Keputusan Pembelian Online”. Jurnal Administrasi Bisnis. Vol. 22 No. 1.

Barnes, Stuart and Vidgen Richard.2001. an Integrative Approach to The Assessment of E-Commerce Quality. Journal of Electronic Commerce Research. 3 (3).

Brata B. H, Shilvana Husani and Hapzi Ali, 2017. The Influence of Quality Products, Price, Promotion, and Location to Product Purchase Decision on Nitchi At PT. Jaya Swarasa Agung in Central Jakarta. Saudi Journal of Business and Management Studies, Vol-2, Iss-4B.

Chaffey, Dave and Smith Mayer. (2013). Internet Marketing Strategy, Implementation and Practice. England: Prentice Hall.

Chang, Kuo-Chien., Nien-Te Kuo., Chia-Lin Hsu., and Yi-Sung Cheng. (2014). "The Impact of Website Quality and Perceived Trust on Customer Purchase Intention in the Hotel Sector: Website Brand and Perceived Value as Moderators". International Journal of Innovation, Management and Technology. Vol. 5 No. 4.

Cindy, Fransisca T. (2014). "Pengaruh Identitas Merek Terhadap Loyalitas Merek Melalui Citra Merek Dan Kepercayaan Merek Toyota". Jurnal Manajemen Pemasaran. Vol. 8 No. 2.

Elrado MH. (2014), Pengaruh Kualitas Pelayanan Terhadap Kepuasan, Kepercayaan dan Loyalitas(Survei pada Pelanggan yang Menginap di Jambuluwuk Batu Resort Kota Batu, Jurnal Administrasi Bisnis (JAB), Vol.15 No.2

Fianto, Achmad Yanu Alif., Djumilah Hadiwidjojo., Siti Aisjah and Solimun. (2014). "The Influence of Brand Image on Purchase Behaviour Through Brand Trust". Business Management and Strategy. Vol. 5 No. 2.

Ganguly, Boudhayan and Satya Bhusan Dash. (2010). "The effects of website design on purchase intention in online shopping: the mediating role of trust and the moderating role of culture". International Journal Electronic Business. Vol. 8 No. 4

Hasanov, Jasur and Haliyana Khalid. (2015). "The Impact of Website Quality on Online Purchase Intention of Organic Food in Malaysia: A WebQual Model Approach”. Procedia Computer Science. Vol. 72 No. 1.

Hausman, A.V., and Siekpe, Sam, J. (2009). "The effect of web interface features on consumer online purchase intentions".. Journal of Business Research. Vol. 62 No. 2.

Herwin dan Dion Dewa Barata. (2016). "Faktor-Faktor yang mempengaruhi Keputusan Membeli dan Kepercayaan sebagai Variabel Mediasi”. Jurnal Bisnis dan Komunikasi. Vol. 3 No. 2.

Jusoh, Z.M. and Ling, G.H. (2012). "Factors Influencing Consumers' Attitude Towards E-Commerce Purchases Through Online Shopping”. International Journal of Humanities and Social Science. Vol. 2 No. 4.

Kotler, P dan K. L. Keller. (2012). Manajemen Pemasaran. Edisi 13. Jilid 1. Alih Bahasa. Bob Sabran. Jakarta: Penerbit Erlangga.

Laudon, K.C., dan Laudon, J.P. (2012). Management Information Systems: Managing the Digital Firm. Eight Edition. Yogyakarta: Penerbit Andi.

Lovelock, Christopher. and Wirtz, Jochen. (2011). Services Marketing: People, Technology, Strategy. 7th Edition. New Jersey: Pearson Education, Inc.

Mahkota, Andy Putra., Imam Suyadi., dan Riyadi. (2014). "Pengaruh Kepercayaan dan Kenyamanan Terhadap Keputusan Pembelian Online (Studi pada Pelanggan Website Ride Inc)". Jurnal Administrasi Bisnis. Vol. 8 No. 2.

Mowen, John C and Minor, Michael. (2012). Consumer Behavior. Edisi Keenam. New Jersey: Prentice-Hall, Inc. Mustikarillah, Rizki N. (2011). "Pengaruh Citra merek Terhadap Pengambilan Keputusan Pembelian Mobil Toyota rush pada PT. Hadji Kalla di Makassar". E-Proceeding of Management. Vol. 1 No. 2.

Peter, J.P. and Olson, J.C. (2006) Customer Behavior and Marketing Strategy, 4th ed., The MC Graw Hill Companies, Inc., USA. 
Piarna, Rian. (2011). "Pengaruh Sumber Informasi dan Kualitas Website terhadap Kepercayaan Pelanggan dalam Menentukan Keputusan Bertransaksi pada E-commerce (Studi pada Pelanggan E-commerce di Indonesia)". Jurnal Aplikasi Manajemen. Vol. 12 No. 1.

Pratiwi, H. D. (2012). "Pengaruh Reputasi Perusahaan dan Kualitas Website Terhadap Tingkat Kepercayaan Konsumen Dalam Bertransaksi Secara Online". Jurnal Administrasi Bisnis. Vol. 11 No. 1.

Sarwono, J. \& Prihartono. (2012). Perdagangan online: Cara bisnis di internet. Jakarta: PT Media Elex Komputindo.

Schiffman, Leon, L. Lazar Kanuk. (2008). Perilaku Konsumen. Alih Bahasa : Zoelkifli Kasip. Jakarta : PT. Indeks.

Shah, Syed Saad Hussain., Jabran Aziz., Ahsan raza Jaffari., Sidra Waris., Wasiq Ejaz., Maira Fatima., and Syed Kamran Sherazi. (2012). "The Impact of Brands on Consumer Purchase Intentions". Asian Journal of Business Management. Vol. 4 No. 2

Shalini G.R and K.S Hemamalini. (2015). "A Study of Online Shopping Webstite Characteristics and Its Impact on Consumer Intention to Purcahse Online in Chennai". International Research Journal of Engineering and Technology. Vol. 2 No. 1.

Sitorus, Tigor dan Roni Hartono. (2015). "Efek Mediasi Customer Trust atas Pengaruh Word of Mouth, Perceived Quality, Brand Image terhadap Purchase Intention”. Jurnal Magister Manajemen. Vol. 8 No. 2.

Sumarwan, Ujang. (2011). Perilaku Konsumen Teori dan Penerapannya Dalam Pemasaran. Edisi 2. Bogor: Ghalia Indonesia.

Suryani, Tatik. (2013). Perilaku Konsumen di Era Internet. Yogyakarta: Graha Ilmu.

Tjiptono, F. (2015). Strategi Pemasaran. Edisi Empat. Yogyakarta: Andi.

Zulastari, Dian Indah dan Aditya Wardhana. (2016). "Pengaruh Citra Merek Bukalapak.com terhadap Keputusan Pembelian Konsumen”. e-Proceeding of Management. Vol. 3 No. 1 